\title{
Preliminary results of tritium analyses in basal ice, Matanuska Glacier, Alaska, U.S.A.: evidence for subglacial ice accretion
}

\author{
JefFrey C. Strasser, \\ Department of Earth and Environmental Sciences, Lehigh University, Bethlehem, PA 18015, U.S.A. \\ DaNiel E. LaWSON, \\ U.S. Army Cold Regions Research and Engineering Laboratory, 72 Lyme Road., Hanover, NH 03755, U.S.A. \\ Grahame J. Larson, \\ Department of Geological Sciences, Michigan State University, East Lansing, MI 48824, U.S.A. \\ EDWARD B. EVENSON, \\ Department of Earth and Environmental Sciences, Lehigh University, Bethlehem, PA 18015, U.S.A. \\ Richard B. Alley \\ Earth System Science Center and Department of Geosciences, The Pennsylvania State University, University Park, PA 16802, U.S.A.
}

\begin{abstract}
The stratified-facies ice of the basal zone of Matanuska Glacier, Alaska, U.S.A., contains significant concentrations of anthropogenic tritium, whereas unaltered englacial-zone ice is devoid of tritium. Supercooled water flowing through subglacial conduits during the melt season likewise contains tritium, as does frazil and other platy ice that nucleates and grows within this subglacially flowing water. These initial results demonstrate net accretion of more than $1.4 \mathrm{~m}$ of stratified basal-zone ice since initiation of above-ground, thermonuclear bomb testing in 1952. Furthermore, these results support a theory of basal ice formation by ice accretion and debris entrainment from supercooled water within a distributed subglacial drainage system.
\end{abstract}

\section{INTRODUCTION}

Numerous mechanisms have been proposed to explain the formation of debris-rich basal ice in temperate and subpolar glaciers (e.g. Weertman, 1961, 1964; Boulton, 1972; Iverson, 1993). In general, the proposed mechanisms of net basal freeze-on rely upon cold ice coming into contact with a wet bed. Ice and sediment may freeze to the sole of a wet-based glacier where it moves over isolated cold patches (Robin, 1976) or within a narrow zone along the glacier terminus where ice is thin $(<30 \mathrm{~m})$ and the winter cold wave penetrates to the bed (Weertman, 1961; Clarke and others, 1984). A similar situation may arise if ice is thinned rapidly during a massive surge (Alley and MacAyeal, 1994). Thicker basal zones $(>1 \mathrm{~m}$ ) have been accounted for by mechanisms of net freeze-on or tectonic thickening (Gow and others,

\footnotetext{
* Now at: U.S. Army Cold Regions Research and Engineering Laboratory, 72 Lyme Road, Hanover, NH 03755, U.S.A.
}

1979; Lawson, 1979; Sugden and others, 1987; Sharp and others, 1994).

Field observations initiated by D. E. Lawson (unpublished data) and theoretical computations by R.B. Alley (unpublished data) based on those observations indicate that an additional mechanism for subglacial freezing is possible, whereby water becomes supercooled in conduits as it flows uphill from a subglacial overdeepening. Where the glacier bed slopes steeply in the direction opposite to the ice surface slope, the pressuremelting point of the flowing water may rise faster than the temperature can increase due to warming by the available heat sources. These sources include geothermal flux, the heat of work done to move the water, and the heat of sliding (Röthlisberger, 1972; Röthlisberger and Lang, 1987). Ice growth can eventually close conduits, however, forcing water into other englacial or subglacial routes which do not have geometries conducive to freezing (Hooke and Pohjola, 1994).

It has been shown, however, that during periods of excessive subglacial discharge, high water pressures can force water into a distributed subglacial drainage system (Iken and others, 1983). In this situation, high water 
pressures partially float the glacier and may raise it by several centimeters or more, thereby maintaining sufficient space for water to continue flowing in spite of ice growth (Iken and others, 1983; Iken and Bindschadler, 1986; Alley, in press). Water may flow through a distributed subglacial system for a significant fraction of the melt season, and given appropriate bed and ice surface configurations, subglacial water will supercool, leading to ice nucleation and growth. Ice growth in low, wide cavities or canals (Walder and Fowler, 1994) may accrete discontinuous layers or lenses of ice to the sole of the glacier (Lawson and others, in press). In this paper, we present evidence from initial analyses of tritium concentrations within ice and subglacial discharge waters of Matanuska Glacier, Alaska, U.S.A. These results demonstrate ice accretion in response to supercooling in the subglacial drainage system.

\section{SITE DESCRIPTION}

Matanuska Glacier flows north-northwest out of the Chugach Mountains from a drainage basin of approximately $665 \mathrm{~km}^{2}$, of which approximately $57 \%$ is covered by ice (Fig. 1). A major tributary of the Matanuska River originates along the western margin of the glacier in the study area (Fig. 2). Within this area, ice flows through a prominent overdeepening, evidenced by the ice surface profile, crevasse patterns and ground-penetrating radar studies (Arcone and others, 1995). The current ice margin is approximately coincident with the down-glacier extent of this overdeepening.

\section{BASAL ICE CHARACTER}

Debris-rich basal ice exposed at the terminus of Matanuska Glacier ranges in thickness from several

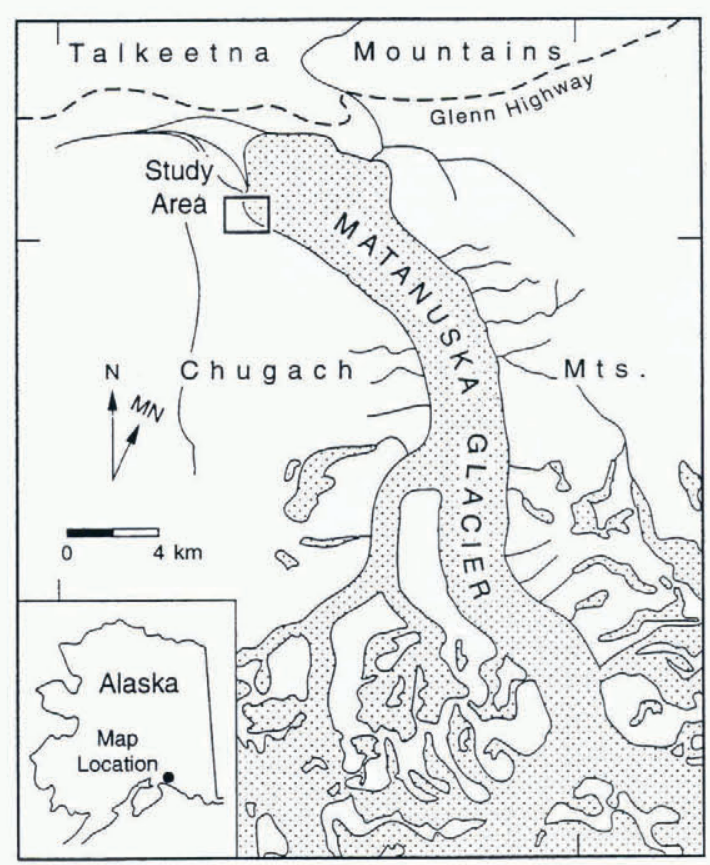

Fig. 1. Site location maps of Matanuska Glacier.

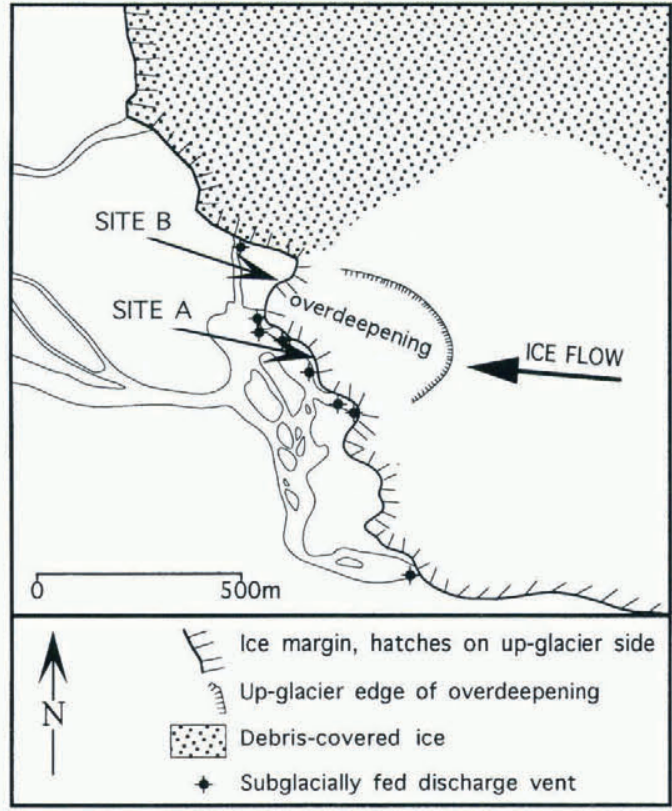

Fig. 2. Sludy area al the terminus of Matanuska Glacier.

meters to $>10 \mathrm{~m}$ in most locations. The basal ice of this glacier has been described by Lawson (1979), who distinguished two facies according to the characteristics of the debris and ice. Most of the debris within the basal zone is transported within the stratified facies (Fig. 3), which is typically bubble-free with bulk sediment concentrations of up to $74 \%$ by volume (Lawson, 1979). Stratifications are expressed as thin $(<2 \mathrm{~cm}$ generally) layers or lenses of solid or clotted silt (Figs 3 and 4), with occasional lenses and lavers of rounded to sub-rounded gravels. Between such strata, lenses of bubble-free ice often contain isolated cobbles and pebbles and aggregates of silt. A second basal ice facies, termed the dispersed facies by Lawson (1979), often exists directly above the stratified facies. The dispersed facies contains less debris $(<5 \%$ by volume), which is dispersed uniformly throughout a $0.2-8.0 \mathrm{~m}$ thick layer of bubblepoor to bubble-free ice Lawson, 1979). Where the dispersed facies is absent, a layer of clear, bubble-free, blue ice of variable thickness overlies the stratified-ice facies. Based on the physical and chemical characteristics, Lawson and Kulla (1978) concluded that the stratified facies formed by basal freeze-on, but the water source and freeze-on mechanism were not identified. The physical and isotopic characteristics of the dispersed facies, however, they attributed to regelation without water loss.

\section{ICE GROWTH IN SUBGLACIAL DISCHARGE}

Platy ice grows within supercooled water which discharges during the melt season from subglacially fed vents and fountains at the terminus of Matanuska Glacier (Fig. 5; Lawson, 1986; Strasser and others, 1992). We use the term "platy" to describe multiple crystals in the form of plates and dendrites which grow in an open framework structure, often in high-velocity, turbulent waters. Ice grows throughout the melt season, when air temperatures remain consistently above freezing, and individual 


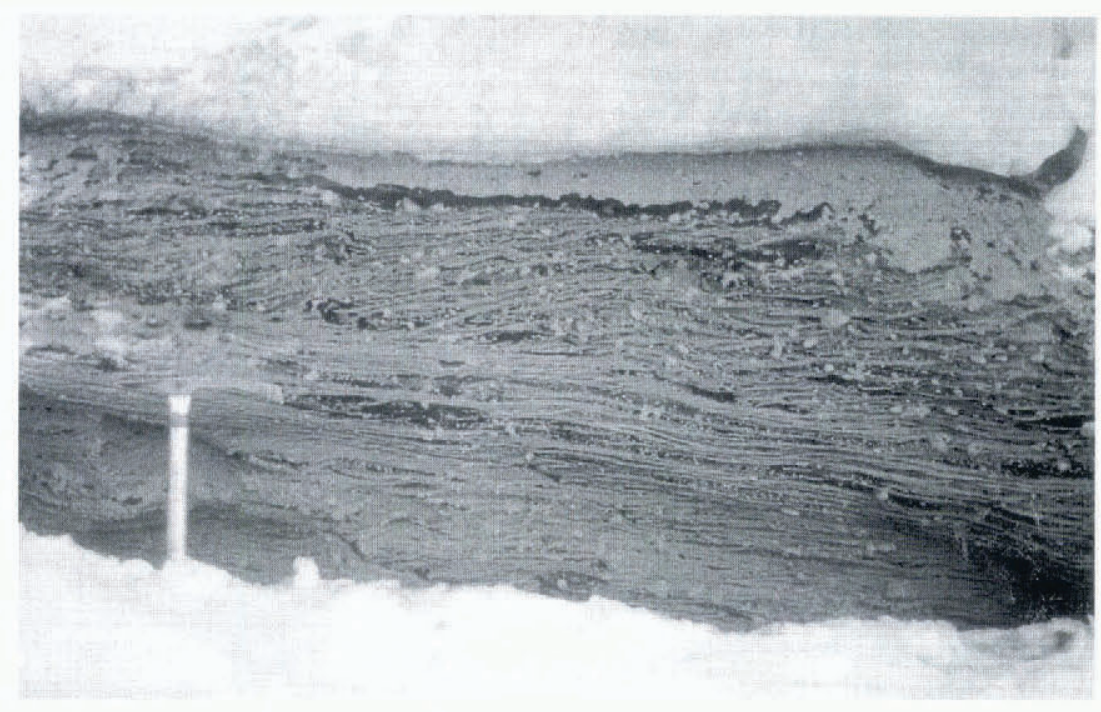

Fig. 3. Stratified basal ice facies, illustrating complex interfingering of debris-rich and debris-poor lenses, discontinuous layers and isolated clasts and clots of sediment.

crystals range from several millimeters to more than $10 \mathrm{~cm}$ in maximum dimensions. Frazil ice is transported within water discharging from vents, and where it adheres to a stable substrate, such as bed materials or ice, it continues to grow as anchor ice, forming rims and terraces which surround the vents (Fig. 5). Platy ice also grows inward from the walls of conduits exposed at the terminus.

Platy ice grows prolifically during periods of high subglacial discharge in July and August. Ice growth around one of the most active vents at the terminus produced a $2 \mathrm{~m}$ high terrace in 2 months, indicating net vertical accretion of more than $3 \mathrm{cmd}^{-1}$. Sediment in transport as both suspended and bed load is commonly deposited within the open framework structure of the platy ice which lines the vents and forms the terraces.

Field observations initiated by D. E. Lawson led to the hypothesis that the stratified facies of Matanuska Glacier originates by accretion of ice from supercooled water flowing uphill within a subglacial overdeepening immediately up-glacier of the present terminus. According to this hypothesis, frazil ice nucleates and grows within a distributed subglacial drainage system of braided conduits or canals. Debris may be entrapped within the openings of platy ice as described above, or simply frozen to the glacier base by growth of anchor ice into the substrate. Subsequent stages of ice growth and debris entrapment over many years may accrete beneath previously formed ice, resulting in sections of stratifiedfacies ice with older ice at the top and younger ice at the bottom (Lawson and others, in press).

\section{METHODS}

As a test of whether the debris-rich, stratified-facies ice is the product of net freeze-on, samples of various ice facies and water types were obtained and analyzed for

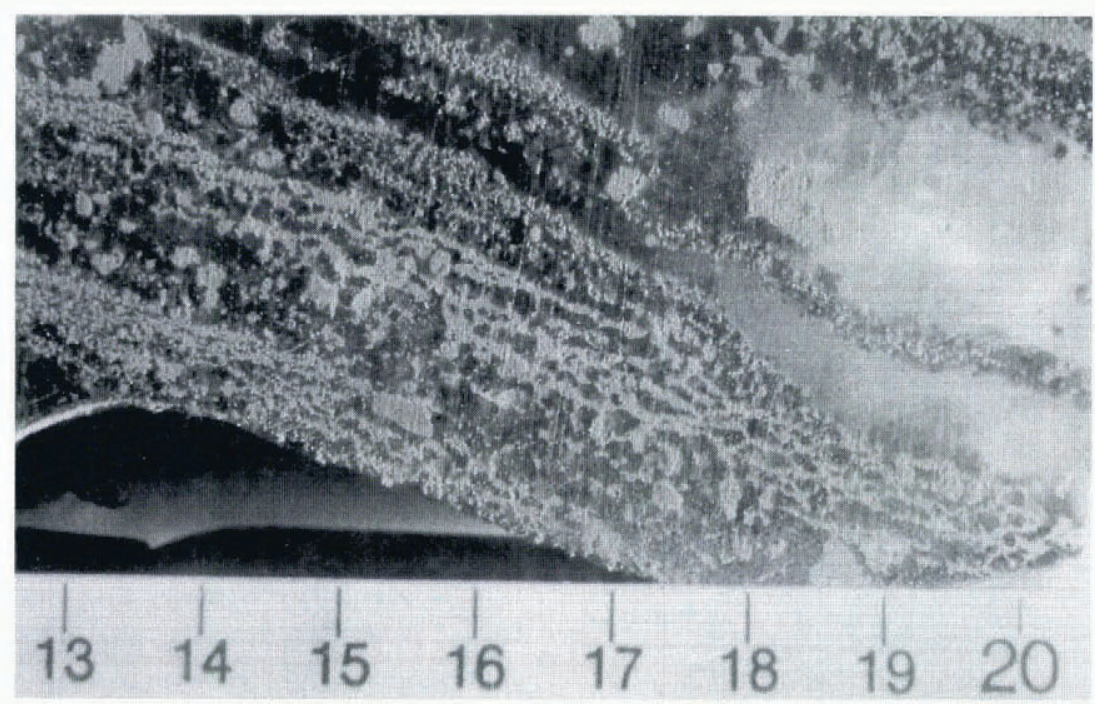

Fig. 4. Close-up photograph of a cut surface of stratified-facies ice within a cold room, illustrating the texture of incorporated debris and the absence of air bubbles. The scale is in centimeters. 


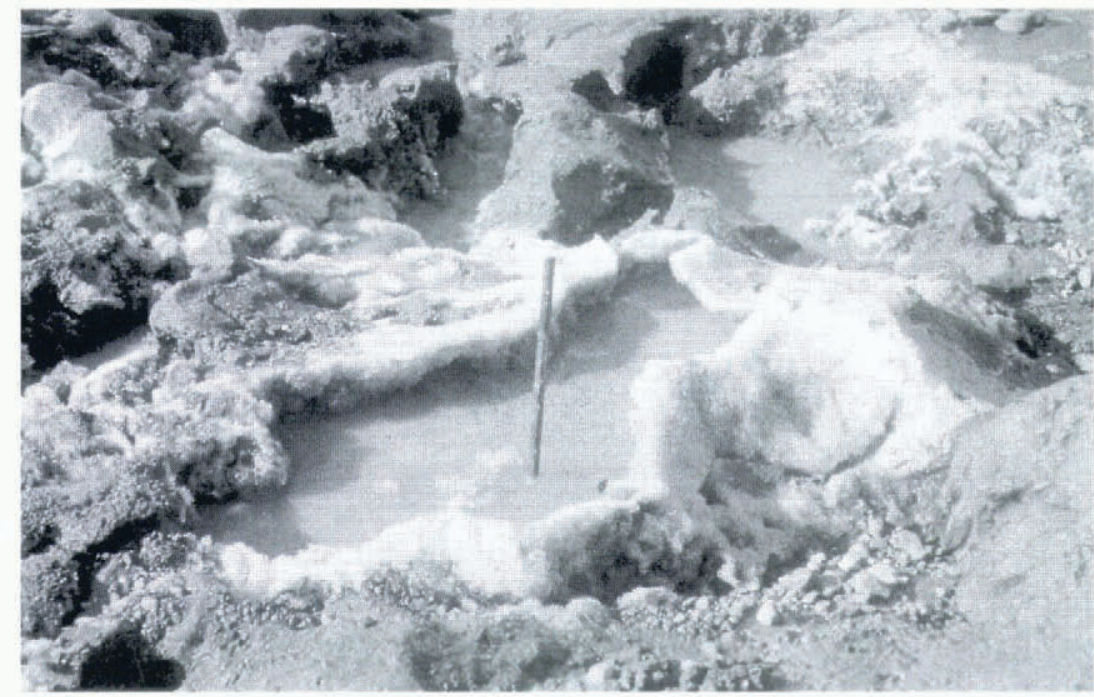

Fig. 5. Subglacially fed, ice-marginal vents with debris-rich accretionary terraces of platy ice. This photograph was taken in the early morning following a rapid drop in discharge and water level, exposing ice which had formed several hours earlier beneath the water surface. The stake extends approximately $35 \mathrm{~cm}$ above the water level.

concentrations of tritium $\left({ }^{3} \mathrm{H}\right)$. Prior to 1952 , tritium levels in precipitation were generally less than $25 \mathrm{TU}$, where $1 \mathrm{TU}=1{ }^{3} \mathrm{H}$ atom per $10^{18}{ }^{1} \mathrm{H}$ atoms Libby, 1955; Gat, 1980). Thermonuclear bomb testing during the $1950 \mathrm{~s}$ and 1960 s released anthropogenic tritium into the atmosphere at levels far exceeding natural background levels. By 1963, tritium levels in precipitation from several locations in coastal and interior Alaska exceeded $3000 \mathrm{TU}$ (Leventhal and Libby, 1970). Atmospheric levels have subsequently decreased to nearbackground levels due to fall-out and radioactive decay $\left(\mathrm{t}_{1 / 2}=12.26\right.$ years $)$.

The present equilibrium line of Matanuska Glacier lies $>30 \mathrm{~km}$ from the terminus; reasonable assumptions of flow velocities of $100-200 \mathrm{~m}$ year ${ }^{1}$ indicate that the age of the englacial ice at the terminus is $>150$ years, and it is probably much older than that. Clean, englacial-zone ice is therefore expected to be devoid of measurable tritium, while the stratified-facies ice is expected to contain measurable amounts of tritium if it formed since 1952 from freeze-on from "young" tritium-rich waters.

Ice samples were obtained in March 1993 from two separate sites at the terminus along the down-glacier edge of the overdeepening (Fig. 2). At site A, samples were taken from two cores $93-1$ and 93-2) obtained through a thin, overhanging ledge of the glacier, using a SIPRE core barrel. Each core was approximately $1.2 \mathrm{~m}$ long, extending from the bubbly englacial ice (diffused facies), through a layer of the basal dispersed facies, and a $15 \mathrm{~cm}$ thick layer of stratified-facies ice at the base. Additional samples of stratified-facies ice were obtained by sampling beneath the overhang along a horizontal transect. The exposed section of stratified-facies ice beneath the overhang at site $\mathrm{A}$ was less than $0.5 \mathrm{~m}$ thick, and therefore all samples of stratified facies were obtained from approximately the same stratigraphic horizon.

At site $\mathrm{B}$, the basal zone was over $2 \mathrm{~m}$ thick, and a vertical profile was sampled, starting from an arbitrarily located point in the overlying englacial-zone ice and extending downward through a very thin layer of the basal-zone dispersed facies and into the stratified-facies ice. Additional ice and water samples obtained in 1993 and 1994 included stratified-facies ice, frazil and anchor ice, subglacial water, ground-water and precipitation.

Samples were analyzed in the low-level tritium laboratory at Michigan State University, using scintillation counting techniques Kessler, 1988). In order to verify analytical techniques, two split samples were also analyzed at the Environmental Isotope Laboratory at the University of Waterloo, Ontario, and the results compared favorably (Table 1). It was anticipated that tritium concentrations would be low (e.g. $<20 \mathrm{TU}$ ) and would thus necessitate electrolytic enrichment Östlund and Werner, 1962). The enrichment process requires $250 \mathrm{ml}$ of original sample water. Each ice sample is therefore an homogenization of a $5-10 \mathrm{~cm}$ thick stratigraphic horizon. The analytical detection limit is $1 \mathrm{TU}$, and the precision is $\pm 1 \mathrm{TU}$. Selected split samples were also analyzed for $\delta^{18} \mathrm{O}$ at the Byrd Polar Research Center, Columbus, Ohio. These latter data provide correlation with previous basal- and englacial-zone analyses of Lawson and Kulla (1978).

\section{RESULTS AND DISGUSSION}

In order to compensate for the decay of tritium in the time between sampling and analysis, results are normalized to reference dates of 31 December 1993 and 31 December 1994 for samples analyzed in 1993 and 1994, respectively. At site $\mathrm{A}$, both cores contained minor concentrations of tritium in the uppermost $5 \mathrm{~cm}$ Fig. $6)$. These samples were obtained from the glacier surface, and each was bubble-poor and contained intercrystalline clots of ash from the 1992 eruption of Mount Spurr in south-central Alaska. It is therefore likely that the uppermost sample from each core was composed of superimposed ice, a component of which was modern precipitation. With depth, samples of bubbly englacial ice and dispersed-facies ice contained little to no tritium 
Table 1. Tritium concentrations in additional samples of ice and water

\begin{tabular}{|c|c|c|c|}
\hline Description & Sample location & $T U$ & Sample No. \\
\hline \multicolumn{4}{|l|}{ Debris-rich } \\
\hline stratified facies & Basal zone & 18.0 & $94-07-01$ \\
\hline \multicolumn{4}{|l|}{ Bubbly, clean } \\
\hline diffused facies & Englacial zone & 0.0 & $94-08-01$ \\
\hline \multicolumn{4}{|l|}{ Clear, clean } \\
\hline diffused facies & Englacial zone & 7.1 & $93-52-02$ \\
\hline Platy ice & Subglacial conduit & $13.2,^{*} 16.5$ & 93-53-01 \\
\hline $\begin{array}{l}\text { Subglacial water } \\
\quad 25 \text { August } 1993,1730 \mathrm{~h}\end{array}$ & $\begin{array}{l}\text { Subglacially fed } \\
\text { discharge vent }\end{array}$ & 6.0 & 93DL-2019-01 \\
\hline $\begin{array}{l}\text { Subglacial water } \\
\qquad 18 \text { May } 1994,1500 \mathrm{~h}\end{array}$ & $\begin{array}{l}\text { Subglacially fed } \\
\text { discharge vent }\end{array}$ & 5.6 & 94-105-01 \\
\hline $\begin{array}{l}\text { Subglacial water } \\
\text { 12 June } 1994,1130 \mathrm{~h}\end{array}$ & $\begin{array}{l}\text { Subglacially fed } \\
\text { discharge vent }\end{array}$ & 4.3 & $94-150-01$ \\
\hline \multicolumn{4}{|l|}{ Rain } \\
\hline 24 August 1993 & Glacier terminus & 8.0 & $93-205-01$ \\
\hline \multicolumn{4}{|l|}{ Snow } \\
\hline 29 September 1993 & Glacier terminus & 7.6 & $93-227-01$ \\
\hline \multicolumn{4}{|l|}{ Ground-water } \\
\hline 14 March $1993,1239 \mathrm{~h}$ & Glacier terminus & 26.0 & $93-27-01$ \\
\hline
\end{tabular}

* Sample analyzed at University of Waterloo.

$(<2 \mathrm{TU})$, while the stratified-facies ice at the base of each core contained greater than approximately 9 TU. Results

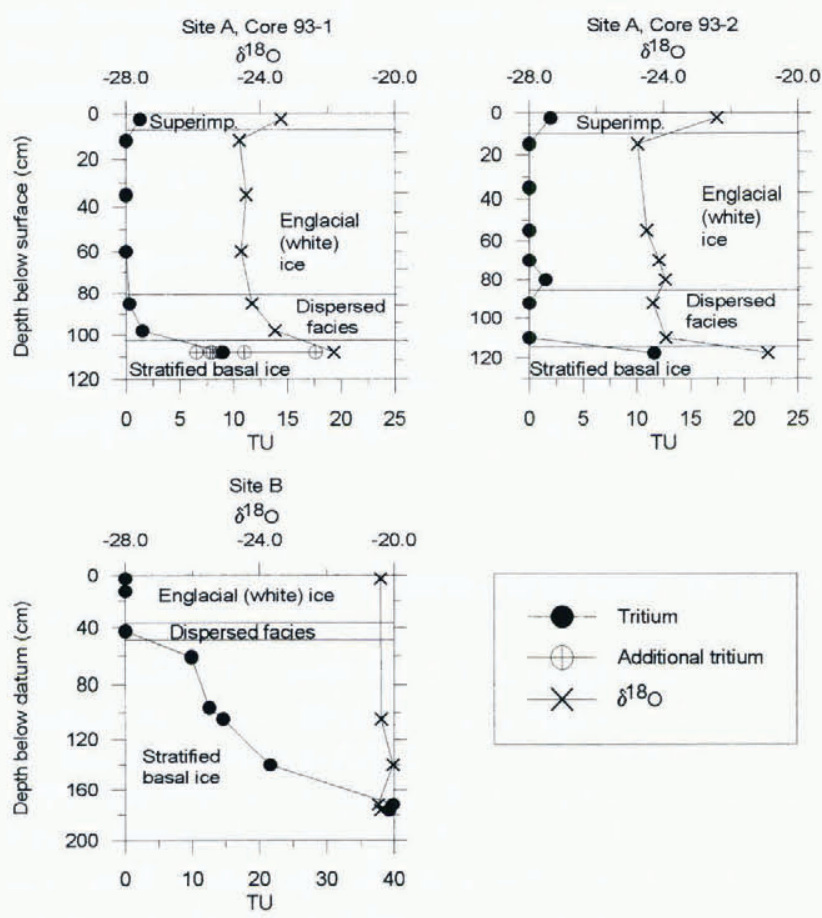

Fig. 6. Tritium concentrations and $\delta^{18} O$ from three different profiles. For core 93-1, eight basal ice samples obtained from the same stratigraphic horizon at site $A$ are plotted in addition to the samples from the core. Tritium concentrations are adjusted to a reference date of 31 December, 1993. from eight additional samples of stratified-facies ice, obtained from the same stratigraphic horizon as the lowermost sample in both cores, are plotted with the data of core 93-1 (Fig. 6). These additional samples also contain significant tritium, with concentrations of approximately $6.5-17.5 \mathrm{TU}$. The $\delta^{18} \mathrm{O}$ data mimicked the tritium data in both cores, with heavier $\delta^{18} \mathrm{O}$ corresponding to greater concentrations of tritium. At site B (Fig. 6), clean ice of the englacial-zone and basaldispersed facies contained negligible amounts of tritium. In contrast, tritium concentrations increased dramatically with depth in the stratified facies. At site $\mathrm{B}$, the $\delta^{18} \mathrm{O}$ was consistently heavy compared to the diffused-facies samples from cores 93-1 and 93-2.

The elevated concentrations of tritium in the stratified facies indicate that this ice is composed in part of water from post-1952 atmospheric sources. In contrast, clean ice of the englacial zone contained negligible tritium, while ice of the dispersed facies contained little to no tritium. Tritium within the stratified facies can be accounted for either by incorporation of young water within preexisting ice, or by the creation of new ice from young water. Water migration along ice grain boundaries from subglacial sources (conduits or films) could theoretically introduce small amounts of tritium-enriched water into the stratified-facies ice, although such a process would contribute only trace amounts of tritium to the basal zone, resulting in significant dilution compared to the subglacial water. Tritium concentrations in the stratifiedfacies ice exceed those of modern subglacial water, however, suggesting that this ice formed several years to decades ago. Moreover, visual and petrographic analyses of the stratified-facies ice indicate that there are no intercrystalline voids along which water could migrate, 
nor is there evidence of secondary intercrystalline ice growth. Furthermore, the absence of air bubbles (Fig. 4) and the heavier $\delta^{18} \mathrm{O}$ than englacial ice indicate an accretionary origin (Gow and others, 1979). We therefore maintain that the stratified ice has formed since 1952 by ice growth from subglacial waters enriched in tritium. Freezing was accompanied by open-system fractionation of ${ }^{18} \mathrm{O}$, resulting in consistently heavy stratified-facies ice in comparison to clean ice of the englacial zone.

The input of tritium to water in the subglacial drainage system and, therefore, to the ice which forms from this water, is a function of the long-term and seasonal variations in tritium within precipitation. The record of tritium concentrations in regional precipitation is presented in Figure 7 unpublished data from R. L. Snyder, U.S. Geological Survey (USGS), with the average annual tritium concentrations corrected for decay to a reference date of 31 December 1993 (Fig. 7). These data were obtained by the USGS in Palmer (1958$65)$ and Anchorage (1966-93), Alaska. Both cities are located within $150 \mathrm{~km}$ of the study area and are generally affected by the same weather systems as the Matanuska Glacier region.

During the 1960 s, tritium concentrations in precipitation fluctuated by several orders of magnitude as a result of sporadic, above-ground thermonuclear testing. The peak in mean annual tritium concentration in 1963 (Fig. 7) corresponds to intense testing during 1962 and 1963 (Leventhal and Libby, 1970). After 1963, tritium concentrations in precipitation declined gradually, although seasonal fluctuations remained evident, with the highest concentrations usually occurring in late spring or early summer. Two precipitation samples obtained in the late summer and early autumn of 1993 contained 8.0 and $7.6 \mathrm{TU}$, respectively (Table 1); these values are consistent with the regional record (Fig. 7).

The wide range of tritium concentrations in the stratified-facies ice presumably reflects the combined effects of tritium variations in precipitation and variable sources of water to the subglacial hydrologic system. Water sources to the subglacial hydrologic system include precipitation, tributary streams, snowmelt, glacial melt- water and ground-water. During the summer, the dominant sources of subglacial water are tributary streams, precipitation and glacial meltwater, with snowmelt a major component in the spring. During the winter, however, the subglacial discharge is only a minor fraction of the typical summer discharge, and water sources are limited primarily to basal melting and ground-water (Lawson, 1986). During the melt season, tributary streams are probably dominated by runoff from rain and snowmelt, and moderate concentrations of tritium are thus expected (e.g. 7-8 TU). Meltwater from pre-1952 glacier ice presumably contains no tritium and therefore dilutes the subglacial water. In contrast, ground-water may contain higher concentrations of tritium. A single sample (93-27-01, Table 1) was obtained from a nearby stream in March 1993, and since snowmelt was negligible at this time of year, we assume that the stream was fed almost entirely by groundwater. The tritium concentration in this ground-water sample was over three times greater than that of modern precipitation samples (Table 1), suggesting a pre-1973 atmospheric water source for the aquifer (Fig. 7). Therefore, if ice accretes subglacially during the winter, when the ground-water component in subglacial discharge is high, its tritium content should be greater than that of ice which forms during the melt season.

Samples of the subglacial water discharging from icemarginal vents during summer contained tritium at concentrations of $46 \mathrm{TU}$ (Table 1), indicating that this water is composed in part of post-1952 meteoric water. Under the assumption that the vent-discharge sample of 6 TU obtained in late August 1993 was composed of only modern precipitation and glacial meltwater, and that the precipitation sample from the previous day $(8 \mathrm{TU})$ was representative, approximately $25 \%$ of the vent discharge was composed of glacial meltwater. If ground-water with higher tritium concentrations (e.g. 26 TU) also contributed to the subglacial discharge, then greater dilution from glacial melt is implied. The vent-discharge sample containing only $4.3 \mathrm{TU}$, obtained during warm, sunny weather in early June, probably reflects even greater dilution by glacial meltwater.

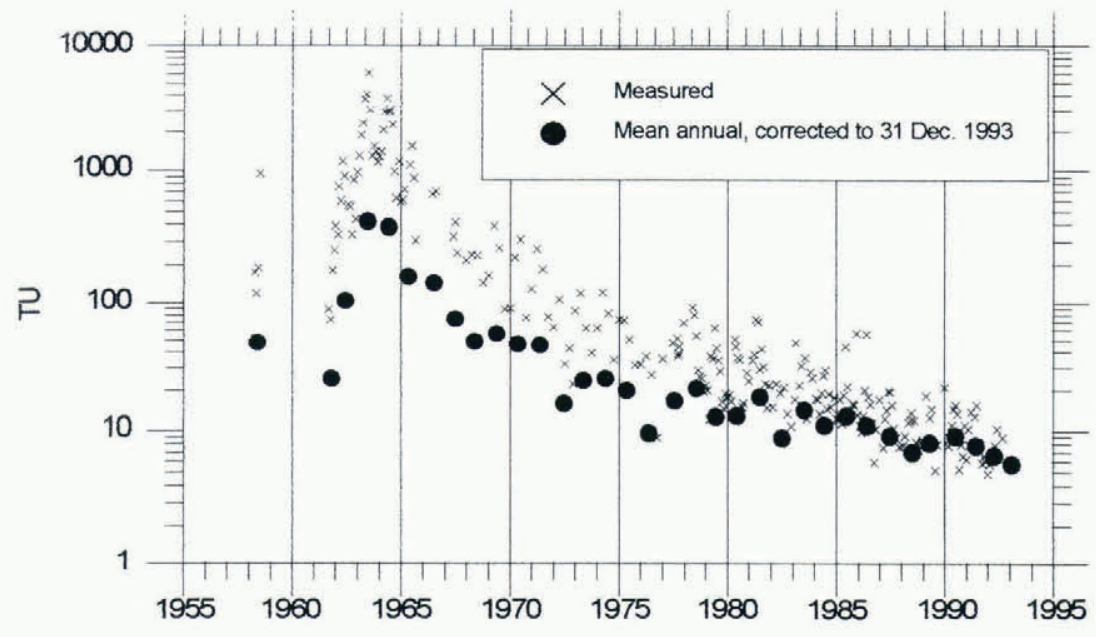

Fig. 7. Tritium concentrations in precipitation sampled in Palmer (1958-65) and Anchorage (1966-93), Alaska. The crosses are tritium values as analyzed, and the heavy circles are mean annual tritium values corrected for decay to a reference date of 31 December, 1993. (Unpublished dala from R. L. Snyder, USGS, Anchorage). 
Fresh platy ice sampled from within a large subglacial conduit contained tritium in excess of 13.2 TU (93-53-01, Table 1), indicating that the tritium concentration in subglacial water varies more than is represented by our limited data set. It should be noted that tritium fractionation during ice growth is negligible compared to background variations in tritium. Isotopic fractionation occurs during a change of state because of differences in the spacing of vibrational levels of the bonds between atoms (typically Van der Waals, but in the case of water mostly hydrogen bonding). This spacing is proportional to the square root of the ratio of masses of the atoms involved in the bonds. Using this model, the relative fractionations of water molecules during a change of state are expected to be in the following ratios: fractionation of $\mathrm{T} / \mathrm{H}$ is expected to be $\sim 1.4$ times that of $\mathrm{D} / \mathrm{H}$; and fractionation of $\mathrm{D} / \mathrm{H} \sim 8$ times larger than that of ${ }^{18} \mathrm{O} /{ }^{16} \mathrm{O}$. The maximum increase in $\delta^{18} \mathrm{O}$ during freezing is approximately $+3 \%$ (O'Neil, 1968; Lehmann and Siegenthaler, 1991). Therefore, the maximum enrichment of tritium in ice is less than $4 \%$, which is insignificant compared to the variations in tritium concentrations within precipitation (Fig. 7) or within subglacial discharge (Table 1).

Elevated levels of tritium in the basal stratified facies are therefore evidence for subglacial ice accretion since 1952. If subglacial accretion occurs in a top-down fashion, then a downward decreasing trend in tritium concentrations would be evident in basal sections formed since 1963 (Fig. 7). At site B, the trend is in the opposite direction, with higher tritium concentrations towards the base (Fig. 6), possibly reflecting ice growth between 1952 and 1963. Alternatively, the stratigraphy may be complicated by non-uniform ice-growth patterns, ice tectonics near the terminus, or variable sources of water to the subglacial hydrologic system. The stratified-facies ice at site B was at least $140 \mathrm{~cm}$ thick, yielding a minimum freeze-on rate of more than $3 \mathrm{~cm} \mathrm{year}{ }^{-1}$, assuming no tectonic thickening occurred. A clearer understanding of the specific freeze-on patterns and processes awaits detailed stratigraphic analyses of tritium concentrations and stable-isotope variations. Nevertheless, the tritium data presented here demonstrate that thick, debris-rich sections of stratified-facies ice can be accreted rapidly within subglacial overdeepenings.

\section{CONCLUSIONS}

Samples of debris-rich basal ice from Matanuska Glacier contained tritium in concentrations ranging from 5 to $40 \mathrm{TU}$, indicating that this ice is in part composed of water that has resided in the atmosphere since 1952. In contrast, englacial-zone ice and dispersed-facies basal ice contain negligible amounts of tritium. These results are consistent with the isotopic and physical data of Lawson and Kulla (1978), who proposed that stratified-facies ice formed by net freezing of externally derived waters and that the dispersed facies originated from regelated englacial ice. Vertical variability in the tritium concentrations of basal stratified ice may reflect a variable source composition, with higher ground-water input leading to higher tritium concentrations. Alternatively, stratified basal ice formed several years to several decades ago is expected to contain higher concentrations of tritium than that formed more recently.

These preliminary data support the hypothesis that subglacial ice growth occurs within water which is supercooled as it flows uphill out of an overdeepening near the terminus of this glacier. Although the formation of ice within englacial conduit flow has been discussed previously (Röthlisberger, 1972; Röthlisberger and Lang, 1987), it may also occur when water is forced subglacially into a distributed system of cavities and low, wide conduits (Lawson and others, in press). Net ice accretion would form discontinuous layers and lenses, incorporating debris within the open framework of frazil ice and other platy forms. Debris-rich basal ice zones may thus accrete at significant rates, perhaps as great as $3 \mathrm{~cm}^{\text {year }}{ }^{-1}$.

\section{ACKNOWLEDGEMENTS}

This research was supported by a grant to E. B. Evenson and D.E. Lawson from the U.S. National Science Foundation (OPP 9223007) and to D. E. Lawson through CRREL (CWIS32689, "Predicting runoff and sediment yield from partly glacierized basins" under the Civil Works Cold Regions Water Resources Program). J. C. Strasser's participation was funded in part by grants from GSA (4810-91 and 5055-92 and Sigma Xi. R.B. Alley thanks NSF OPP, NASA-EOS and the D. and L. Packard Foundation for funding. We thank R. L. Snyder of USGS for providing valuable data on regional tritium concentrations in precipitation, and L. T. Thompson at the Byrd Polar Research Center for stable-isotope analyses. We also thank J. Klein of the University of Pennsylvania for his discussions of isotopic fractionation.

\section{REFERENCES}

Alley, R. B. In press. Toward a hydrologic model for computerized icesheet simulations. Hydrological Processes.

Alley, R. B. and D. R. MacAveal. 1994. Ice-rafted debris associated with binge/purge oscillations of the Laurentide ice sheet. Paleoceanography, $9(4), 503511$.

Arcone, S. A., D. E. Lawson and A.J. Delaney. 1995. Short-pulse radar wavelet recovery and resolution of dielectric contrasts within englacial and basal ice of Matanuska Glacier, Alaska, U.S.A. . \% Glaciol., 41 (137), 68-86.

Boulton, G. S. 1972. The role of thermal régime in glacial sedimentation. Inst. British Geogr. Spec. Pub., 4, 1-19.

Clarke, G. K. C., S. G. Collins and D. E. Thompson. 1984. Flow, thermal structure, and subglacial conditions of a surge-type glacier. Cian. J. Earth Sci., 21 (2), 232-240.

Gat, J. R. 1980. The isotopes of hydrogen and oxygen in precipitation. In Fritz, P. and J.C. Fontes, eds. Handbook of environmental isotope geochemistry. Amsterdam, Elsevier, 21 - 47.

Gow, A.J., S. Epstein and W. Sheehy. 1979. On the origin of stratified debris in ice cores from the bottom of the Antarctic ice sheet. I. Glaciol., 23 89), 185-192.

Hooke, R. LeB. and V.A. Pohjola. 1994. Hydrology of a segment of a glacier situated in an overdeepening, Storglaciären, Sweden. f. Glaciol., 40 (134), 140-148.

Iken, A. and R.A. Bindschadler. 1986. Combined measurements of subglacial water pressure and surface velocity at Findelengletscher, Switzerland: conclusions about drainage system and sliding mechanism. J. Glaciol., 32 110), 101-119.

Iken, A., H. Röthlisberger, A. Flotron and W. Haeberli. 1983. The uplift of Unteraargletscher at the beginning of the melt season a consequence of water storage at the bed? J. Glaciol., 29 (101), 28-47. 
Iverson, N.R. 1993. Regelation of ice through debris at glacier beds: implications for sediment transport. Geology, 21 (6), $559-562$.

Kessler, M.J. 1988. Effective use of low level liquid scintillation analysis. Proceedings, Second International Seminar for Liquid Scintillation Anabsis, 8 June 1988. Tokyo, Japan. 256-301.

Lawson, D. E. 1979. A sedimentological analysis of the western terminus region of the Matanuska Glacier, Alaska. CRREL Rep. 79-9.

Lawson, D. E. 1986. Observations on hydraulic and thermal conditions at the bed of Matanuska Glacier. Mlaska. Eidg. Tech. Hochschule, Zürich. Tersuchsanst. Wasserbau, Hydrol. Glaziol. Mitt. 90, 69-71.

Lawson, D. E. and J. B. Kulla. 1978. An oxygen isotope investigation of the origin of the basal zone of the Matanuska Glacier, Alaska, f. Geol., 86 6), 673-685.

Lawson, D. E., E. B. Evenson, J. C. Strasser, R. B. Alley and G.J. Larson. In press. Subglacial supercooling, ice accretion, and sediment entrainment at the Matanuska Glacier, Alaska. Geological Society of America, Abstracts with Programs, 28.

Lehmann, M. and U. Siegenthaler. 1991. Equilibrium oxygen- and hydrogen-isotope fractionation between ice and water. J. Glaciol., 37 (25), $23-26$.

Leventhal, J.S. and W.F. Libby, 1970. Tritium fallout in the Pacific United States. J. Geophys. Res., 75 36), 7628-7633.

Libby, W. F. 1955. Tritium in nature. J. Washinglon Acad. Sci., 45 10), $301-314$

O'Neil, J. R. 1968. Hydrogen and oxygen isotope fractionation between ice and water. 7. Phss. Chem., 72 10), 3683-3684.

Östlund, H.G. and E. Werner. 1962. The electrolytic enrichment of tritium and deuterium for natural tritium measurements. Tritium in the Physical and Biological Sciences. Proc. Int. Atomic Energy Agency, 1. 95 105.

Robin. G. de Q. 1976. Is the basal ice of a temperate glacier at the pressure melting point? F. Glaciol., 16 74), 183-196.

Röthlisberger, H. 1972. Water pressure in intra- and subglacial channels. J. Glaciol., 1162 , $177-203$.

Röthlisberger, H. and H. Lang. 1987. Glacial hydrology. In Gurnell, A. M. and M.J. Clark, eds. Glacio-fluial sedimenl transfer: an Alpine perspective. Chichester, U.K., John Wiley and Sons, 207-284.

Sharp, M., J. Jouzel, B. Hubbard and W. Lawson. 1994. The character, structure and origin of the basal ice layer of a surge-type glacier. $\mathcal{J}$. Glaciol., 40 135), 327-340.

Strasser, J. C., D. E. Lawson, E. B. Evenson, J. C. Gosse and R. B. Alley. 1992. Frazil ice growth at the terminus of the Matanuska Glacier, Alaska, and its implications for sediment entrainment in glaciers and ice sheets. Geological Sociely of America, Abstracts with Programs, 24 3) 78.

Sugden, D. E. and 6 others. 1987. Evidence for two zones of debris entrainment beneath the Greenland ice sheet. Vature. 3286127 ). 238241.

Walder, J.S. and A. Fowler. 1994. Channelized subglacial drainage over a deformable bed. J. Glaciol., 40 134), 3-15.

Weetman, J. 1961. Mechanism for the formation of inner moraines found near the edge of cold ice caps and ice sheets. f. Glaciol., 330 , 965978.

Weertman, J. 1964. The theory of glacier sliding. J. Glaciol., 5 39), 287 303. 